Article

\title{
Voice of the Church: A Debate about Religious Radio Stations as Community Broadcasters
}

\author{
Gabriella Velics ${ }^{1, *}$ and Urszula Doliwa ${ }^{2}$ \\ ${ }^{1}$ Department of Communication and Media, University of West-Hungary, 9700 Szombathely, Hungary; \\ E-Mail: velicsg@btk.nyme.hu \\ ${ }^{2}$ Department of Humanities, University of Warmia and Mazury, 10-725 Olsztyn, Poland; \\ E-Mail: urszula.doliwa@uwm.edu.pl \\ * Corresponding author
}

Submitted: 30 May 2015 | In Revised Form: 14 October 2015 | Accepted: 3 November 2015 |

Published: 29 December 2015

\begin{abstract}
In the Declaration of the Committee of Ministers on the role of community media in promoting social cohesion and intercultural dialogue passed on 11 February 2009 by the Council of Europe, stations run by religious institutions were explicitly excluded from the community media definition, as being too dependent on the Church. But the reality seems to be far from this definition. In practice, in many countries the religious radio stations officially belong to-or even dominate-this sector. In 2011 a new period began for community broadcasting in Hungary. While most of the former community media broadcasters could not find resources with which to operate, the community media landscape was dramatically overwhelmed by religious broadcasters both on regional and local levels. The legally-recognised third tier of broadcasting in Poland called 'social broadcasting' is actively and exclusively used by religious radio-seven stations broadcast locally and one is a powerful nationwide radio station called Radio Maryja. The authors gathered information and points of views from radio experts, organizations and activists living and working in different EU and non-EU states about the place of religious broadcasting in the community media sector. Two case-studies (Hungary and Poland) may be of interest for countries considering the introduction or reorganisation of regulations regarding community broadcasting.
\end{abstract}

\section{Keywords}

community radio; Hungary; media policy; Poland; religious broadcasters

\section{Issue}

This article is part of the special issue "Turbulences of the Central and Eastern European Media", edited by Epp Lauk (University of Jyväskylä, Finland).

(C) 2015 by the authors; licensee Cogitatio (Lisbon, Portugal). This article is licensed under a Creative Commons Attribution 4.0 International License (CC BY).

\section{Introduction}

In the Declaration of the Committee of Ministers on the role of community media in promoting social cohesion and intercultural dialogue passed on 11 February 2009 by the Council of Europe, stations run by religious institutions were explicitly excluded from the community media definition, as being too dependent on the Church. However, Church radios easily get community broadcasting licences in some countries of the EU. This article has been inspired by the unclear situation of re- ligious broadcasting in the community media sector, a growing number of religious broadcasters in the legal framework of community media service (közösségi médiaszolgáltatás) in Hungary, as well as the third sector of broadcasting in Poland, known as social broadcasters (nadawcy społeczni), which is monopolized by religious stations. Some inspiration has also resulted from the round table of media experts and practitioners from the community media field organised by the authors on 8th November 2014 during the Bundesverband Freier Radios congress in Berlin/Potsdam 
Zukunftswerkstatt Community Media 2014, where representatives from several countries (Austria, Germany, Ireland, Netherlands, Spain, Sweden, UK) met. It was a unique chance to collect data about the relation between community media and religious stations in Europe. During this conference several questions were raised: Should we consider religious radios as community broadcasters or different entities? What are the arguments for and against including church radio in the community sector? What kind of licences do religious radio have country by country?

In this article we concentrate on radio community broadcasting. When we talk about community media and community broadcasting we mainly have community radio in mind. One of the reasons for this is that according to the 2012 mapping made by Community Media Forum Europe, community radio outnumbers other forms of community broadcasting in Europe (CMFE, 2012) ${ }^{1}$. The other reason is the fact that there are only radio community broadcasters in Poland and Hungary ${ }^{2}$.

\section{Religious Broadcasting versus Community Broadcasting: Definitions}

There are several factors, which play a significant role in the perception of the community media concept. The histories of the sector in a particular state, as well as the current community media practices are important here. Also, the existing legal framework determines the way of thinking about community media to a large extent. The place where you live is important-for example the experience of communist regimes deeply affects the level of development and understanding of community media in Central and Eastern Europe (Doliwa \& Rankovic, 2014). Apart from the abovementioned factors, community media seems to be such a complex and diverse phenomenon that it defies clear-cut descriptions.

However, undoubtedly there are some definitions, which play a primary role, when characterizing what the community media is and what it is not. The authors analyse those definitions looking for some tips suggesting whether religious broadcasting should be or should not be considered as part of community broadcasting, and conditions that must be fulfilled by a religious broadcaster to become a fully-fledged part of this sector. In the European context one should include-in the set of the definitions important for understanding what community media is - the Community Radio Charter for Europe adopted on 18 September 1994 in Ljubljana, Slovenia at the first AMARC Pan-European

\footnotetext{
${ }^{1}$ In 2012 there were 2237 community radio stations counted in 29 European countries (with only 521 community televisions).

2 The exceptions are two cable TV channels with a special licence for social broadcasting in Poland.
}

Conference of Community Radio Broadcasters (AMARC, 1994). It is worth underlining that in this document-formulated by representatives of community media-religious stations as a form of broadcasting usually owned by Church are highlighted as those not belonging to the sector. Point four of this document states that community media are editorially independent of government, commercial and religious [emphasis added] institutions and political parties in determining their programme policy. Also other elements of this definition may prove to be difficult to fulfil by religious broadcasters as for example: free flow of information and opinions, providing a right of access to minority and marginalised groups and promoting and protecting cultural and linguistic diversity; providing a right of reply to any person or organisation subject to serious misrepresentation; operate management, programming and employment practices which oppose discriminations and which are open and accountable to all supporters, staff and volunteers. Fulfilling those requirements might be difficult for religious broadcasters because the mission of such stations is often connected with promoting values and religion represented by the Church. It is not impossible, yet difficult to imagine that, for example, a Muslim or Catholic station would broadcast programmes, which hurt their principles, such as an LGBT programme.

A similar problem with accessibility and diversity of the programmes can be observed also in stations defining themselves as radios addressing their programme not to a local community but the community of interest, which is not a rarity in community broadcasting. How to answer to the needs of groups at present marginalised or ignored by mainstream radio while at the same time avoiding the ghettoization that separate channels might create is a real challenge for such stations, already identified by Peter Lewis in 1984 (p. 148). We should remember that this definition is a list of some aspirations that community media representatives have agreed on. As it was admitted by Sally Galiana, the President of AMARC Europe, AMARC is aware of the fact that the situation is sometimes completely different at a country level from AMARC definitions and documents (e.g. European Charter for Community Radio) and AMARC Europe doesn't want to impose its regulations (Galiana, 2014).

Community media as an important sector of broadcasting in Europe has been also recognized by several European institutions-first of all the European Parliament, which in 2008 adopted a Resolution of the Community Media in Europe (2008/2011(INI)). In the definition, which we can find in this document adopted by representatives of all member states of the European Union, there are no elements which can be recognized as a suggestion that religious broadcasters should be excluded from the sector. Of course, some of the postulates may be difficult to fulfil for religious broad- 
casters, for example; being open to participation in the creation of content by members of the community, who may participate in all aspects of operation and management (European Parliament, 2008). Yet one can find many other examples of community stations around Europe with similar difficulties.

In another important document at the European level-the Declaration of the Committee of Ministers on the role of community media in promoting social cohesion and intercultural dialogue passed on $11 \mathrm{Feb}$ ruary 2009 by the Council of Europe, stations run by religious institutions were, again, excluded from the community media definition. The features of community media are characterized in this document as follows:

Independence from government, commercial and religious [emphasis added] institutions and political parties; a not-for-profit nature; voluntary participation of members of civil society in the devising and management of programmes; activities aiming at social gain and community benefit; ownership by and accountability to the communities of place and/or of interest which they serve; commitment to inclusive and intercultural practices (Committee of Ministers of the Council of Europe, 2009).

When talking about this definition it is worth knowing how it was created and what the principles for people working on this definition were. The Community Media Forum Europe (the organisation representing community broadcasters in Europe) has been working as an observer in the Steering Committee on the Media and New Communication Services (CDMC) of the Council of Europe since December 2007 and contributed actively to drafting this Declaration, cooperating with AMARC Europe. As it was reported by Nadia Belardi-a vicepresident of Community Media Forum Europe and one of the co-creators of this document-the draft of this document was to some extent prepared by the Secretariat of the Steering Committee and based on the previous studies, especially the one made by Peter Lewis, entitled Promoting Social Cohesion (2008). Yet the definition must have come from the observers representing the sector. Nadia Belardi reported the process of adding the element about the exclusion of stations dependent on religious institutions as follows:

independence from religious institution was a very important topic especially for the delegation from France because of the Islamic debate in this country. So probably that is what political representatives had in mind when they were thinking about religious institutions, not necessarily the Catholic Church. Perhaps it is my personal interpretation, but I would say that the biggest fear was funding and legalizing media that can make propaganda for values and practices that go against the democratic values of the European Union and Council of Europe. I don't think that the topic of Catholic or Christian Church radios ever came up to be honest. If there was any discussion we were talking about what is happening in the Balkans, ex-Yugoslavia and the role of the media played there in creating disinclination between various religious communities there. That was a concern. That's what was behind it (Belardi, 2014).

All aspects considered, one can say that religious broadcasting is treated as being outside the community sector in some definitions taken from important European documents dealing with this subject matter. However, it is worth underlining that there is no universally accepted definition of community media. Even the authors of those definitions admit that the character of some of them is often aspirational and far from the real situation in some countries. That is why, when talking about religious broadcasting as part of the community media sector, it is important to look not only at definitions created at the pan-European level but also at opinions of media experts and community media activists as well as at practices and regulations in various countries.

\section{Opinions of Media Experts and Community Media Activists about Religious Broadcasting as Part of the Community Media Sector}

A round table of media experts and practitioners from the community media field was organised by the authors of this article on 8th November 2014 during the Bundesverband Freier Radios congress in Berlin/Potsdam Zukunftswerkstatt Community Media $2014^{3}$. Most of the participants declared: religious broadcasters should not have access to the community media sector. The reasoning was diverse but often included arguments such as dominant ownership, not a non-profit character, dogmatic voice etc.

My militant opinion: religion is private and should be excluded from public service and non-commercial media sector-Michael Nicolai, Germany.

For me the ownership is a key. In my opinion community radio cannot be owned by the Church-

\footnotetext{
3 Participants of the round table discussion: Austria: Judith Purkarthofer-CMFE and University of Vienna ; Germany: Lutz Helm-Radio Blau; Michael Nicolai-AMARC Europe and Radio Corax; Hungary: Joost van Beek-Central European University, Ireland: Sally Galiana-AMARC Europe and Near FM, Ciarán Murray-CMFE and Near FM; Italy: Nadia Belardi-CMFE; The Netherlands: Pieter de Wit-CMFE; Spain: Miriam MedaAMARC Europe and Spanish Community Media Federation; Sweden: Christer Hederström-CMFE; United Kingdom: Jaqui Devereux-CMFE and Community Media Association; Pakistan: Shujaat Ali Khan-Hazara University.
} 
Judith Purkarthofer, Austria.

Accessibility is a key. It is not about excluding religious groups; they exclude themselves because you are not a community broadcaster when you are not accessible to every member of the community. But it is true that we have to reflect cultural realities of different countries. In some of them religion plays a very important role in the society-Sally Galiana, Ireland.

However, the participants of the round-table discussion were also open to talking about forms of religious content acceptable for them in the community media sector. Most of them declared that religious minority groups should have an opportunity to be involved in a local community radio, and prepare programmes alongside other groups, but not to dominate a station. They also strongly believed in the power of selfstandards of the radio, which give the same conditions to any group involved in broadcasting. It was even stated it depends on how much they involve no-faith or other-faith members of the community. It was also underlined that religious broadcasters should fulfil all or most of the criteria, as outlined by international documents. Thus including them into the community media sector is acceptable when religious groups work openmindedly and share the values of the community media. However, the biggest concern was raised by the fact that they operate only in the dominant religious manner and communicate different issues solely in a dogmatic way.

If they haven't got a discussion full of hate speech, I think they should integrate into the program of community stations. But I cannot find any sense in being separated (mainly for themselves) from the rest of the community. I don't agree with the concept of 'religious radio'-Miriam Meda, Spain.

Religious minorities should have the opportunity to take part in community radios if they do not advocate discrimination, e.g. homophobia-Lutz Helm, Germany.

You don't expect to have one dogmatic opinion in community media, that is why religious broadcasting shouldn't be one of the forms of community broadcasting. They fulfil some of the criteria but not all, and it's not the good way to let a dominant voice rule in the backstage-Ciarán Murray, Ireland.

If they are 'community oriented' but not 'community governed', that should not be good enoughPieter de Wit, The Netherlands.

Another feasible suggestion emerged during the discussion-religious broadcasters should have an opportunity to obtain a different kind of licence, not the same as community broadcasters, so they could be regulated and measured by different standards.

I think they should get their own licence, separate and different from community radio, as they don't fulfil basic requirements to be included in the community radio sector. I wouldn't say that they don't have the right to broadcast but I think that they should have a separate licence because they cannot fulfil the accessibility issue so they cannot have a community radio license-for example religious licences or special interest licences because they are not community radios. In Ireland it is possible to ask for "special interest licence" for example-Sally Galiana, Ireland.

However, introducing a scheme for religious broadcasting different than for community media may cause, in Christer Hederström's opinion, some problems, which he summarized as follows:

It is very important when you lobby in different institutions to lobby for a not a very complicated model because when politicians have 5-7 different sectors it is very difficult for them to sort it out. That is why it is sometimes better to let religious groups broadcast in the framework of community broadcasting, especially when they share the frequency with other groups like in Scandinavia. But they shouldn't have their own community radio station. The Nordic and Netherland model is fine. Religious groups (or any other groups) shouldn't be able to have a monopoly on a community radio frequency or a community TV channel.

\section{Religious Broadcasting as Part of the Community Media Sector}

It is worth emphasising that religious broadcasting as part of the community media sector has a long tradition in non-European countries which were not only pioneers in the development of community broadcasting but maintain a strong sector to this day-especially the USA and Australia. In Australia there are more than 360 community radio licences and over 80 community television licences (Community Broadcasting Association of Australia et al., 2010). Christian stations make up almost 10 per cent of all community radio stations, with 36 full-time Christian stations. In America religious broadcasters are mostly active in the form of Low Power Broadcasting-small scale community radios. LPFM stations are authorized for non-commercial educational broadcasting with a power of 100 watts or less (Federal Communications Commission, 2014) ${ }^{4}$. Accord-

\footnotetext{
${ }^{4}$ Federal Communications Commission, Low Power FM Broadcast Radio Stations, http://www.fcc.gov/encyclopedia/low-
} 
ing to the data from 2009: $46 \%$ of licences in the USA for LPFM were given to religious broadcasters (Connolly-Ahern, Schejter, \& Obar, 2012).

In practice, religious radio stations in many European countries also officially belong to the community sector. In the UK there are several different religious radios (Muslim ${ }^{5}$, Christian ${ }^{6}$, Panjabi ${ }^{7}$, etc.) working under a strict licensing regime for community media. As with all the other community broadcasters, they have to show in what sense the community can benefit from their station and, after fulfilling these criteria, they have to aim at social gain, etc. no matter if the community broadcaster is religious or not.

In Sweden only some religious programmes are broadcasted on community channels, but there is no church community radio there. Religious organisations have the right to broadcast on community radio or community TV alongside other organisations, as usual by sharing the opportunity in a given settlement or area. As it was explained by Christer Hederström in Potsdam: In general it's very difficult to take control over a community radio frequency because they have to share the frequency with other groups interested in broadcasting in the city, that's why there is no problem with religious broadcasting in Nordic countries. However, there is another tendency observed in Swedenminority radio stations are becoming more and more religion-oriented.

In Austria religious broadcasters belong to the private radio sector (Radio Maria ${ }^{8}$, Radio Stefansdom ${ }^{9}$ ) and are not allowed to apply for the community radio funding ${ }^{10}$. The criteria of such a financing scheme were developed in cooperation with the Association of Austrian Community Radios.

In Ireland, one Christian radio station (Life FM) ${ }^{11}$ has a community radio licence and is a member of CRAOL, the Community Radio Forum of Ireland. This is the same type of community licence that campus radio and Irish language radio use, and is legally called a 'community of interest station.' In Ireland it is possible to apply for a 'special interest licence', which is different from the community radio licence. The only other Christian radio, Spirit Radio ${ }^{12}$, broadcasting in Ireland, has such a licence and broadcasts on a quasi-national basis.

In the Netherlands there are no religious radio broadcasters except for those transmitting on mid-

power-fm-broadcast-radio-stations-lpfm

${ }^{5}$ Unity FM (Birmingham): http://www.unityfm.net

${ }^{6}$ Flame FM: http://www.flamefm.co.uk

${ }^{7}$ Desi Radio (Southall, London) http://www.desiradio.org.uk

${ }^{8}$ Radio Maria: http://www.radiomaria.at

${ }^{9}$ Radio Stefansdom: http://www.radiostephansdom.at

${ }^{10}$ Austrian Media Regulation: https://www.rtr.at

11 LifeFM: http://www.lifefm.ie/life/Index.html

12 Spirit Radio: http://www.spiritradio.ie wave (AM), but, as in Germany, they are not part of the community radio system. To understand the Dutch case: there are no separate licences for religious groups, young groups etc., there is only an opportunity to apply for a local community licence controlled by representatives of different groups present in the given community.

The German religious sector ${ }^{13}$ was given noncommercial licences and such stations are subsidized by taxes, using public money even if they are eventually active in the framework of commercial broadcasting. This does not, however, seem to be fully acceptable for members of the society. As Michael Nicolai summarized it in Potsdam: They do private radio with public money, which is something weird.

The case of Spain is very complex and selfcontradictory. The Spanish legal regulation ${ }^{14}$ recognized community media, but did not specify if community media can be cultural, religious, etc. In practice community broadcasters exist, but they do not have community media licences. Community broadcasters in Spain are illegal no matter if they are religious or notsummarized Miriam Meda. In a country where one of the largest national radio stations $\left(\mathrm{COPE}^{15}\right)$ is $50 \%$ owned by the Catholic Church, currently regional and national laws regarding audiovisual broadcasting do not speak about religious communities or religious broadcasting ${ }^{16}$.

To sum up, some countries treat religious broadcasting as a form of community media, some of them allow religious stations to broadcast on the basis of slightly different regulations or in the commercial broadcasting scheme. This is related to the history of broadcasting in particular countries, their political system and culture of the society, as well as the degree of its religiousness. Yet the existence of religious broadcasting in the legal framework constructed for community broadcasting should not be treated as something very uncommon. The problem becomes more serious when the religious broadcasting begins dominating other forms of community broadcasting, which seems to be the case in Poland and Hungary. In this article, we

\footnotetext{
${ }^{13}$ Radio Horeb: http://www.horeb.org

Münchener Kirchenradio: http://www.muenchner-kirchen nachrichten.de/muenchner-kirchenradio.html

Domradio: http://www.domradio.de

Radio Maria: http://www.phonostar.de/radio/radiomaria/ deutschland

14 Ley 7/2010, de 31 de marzo, General de la Comunicación Audiovisual. General Law on Audiovisual Communication. (31.03.2010.) Retrieved from http://noticias.juridicas.com/ base_datos/Admin/l7-2010.html

${ }^{15}$ COPE: http://www.cope.es

${ }^{16}$ Radio Maria: http://www.radiomaria.es

In Catalonia, there is one Adventist station: http://eud. adventist.org/news/detail/date/2014/09/11/spain-adventistradio-station-obtains-important-licence
} 
bring evidence to prove this argument by outlining the historical and sociological background of this phenomenon, as well as analysing the legal framework of the third sector of broadcasting in these countries. The current situation of the religious broadcasters existing as part of community broadcasting sector in Poland and Hungary is also described.

\section{Hungary}

The history of the Hungarian community broadcasting sector can be divided into four periods: before 1996, 1996-2002, 2002-2010, and since 2011.

Before 1996, broadcasting was a state monopoly, there were only a few pirate radio stations broadcasting during the events of 1956 in Hungary and 1968 in Czechoslovakia (Cs. Kádár, 2004, pp. 17-22). Alternative broadcasting could be heard for the first time in Hungary after the change of the regime in 1991. Tilos Radio (Forbidden Radio) began broadcasting on 21 August 1991, working as a pirate radio at first.

The first media law of the new era-Act I of 1996 on radio and television broadcasting (Parliament of the Republic of Hungary, 1996)-adopted by the Parliament at the end of 1995, dealt with the community radio stations on a financial basis and labelled them as 'non-profit purpose programme providers'. The conditions in Act I of 1996-such as strictly for non profit operation ( $\S 2(34)$ ) and only 3 minutes advertisement in each programme hour ( $\$ 16(5))$-led the emerging community media sector into a serious crisis, and by the turn of the millennium, community radio broadcasting had lost its importance. It was the era of emerging local commercial radio stations.

In 2002 the National Radio and Television Commission, seeing the unsatisfactory situation in the community sector, launched an application system for the so called 'small community radio' stations, with limited technical parameters e.g. the output of the transmitter must not be over 10 Watts and the height of the antenna must not be over 30 meters, with a typical maximum coverage area: one kilometre stereo and two kilometres mono.

All these regulations may be viewed in two ways. The new application system made it possible to create non-profit local broadcasting as a unique phenomenon in Eastern Europe, with relatively simple legal and technical conditions, but on the other hand, the strictly limited parameters did not ensure effective operation. By the end of 2010, 68 small community radio stations were already broadcasting in 53 areas across Hungary. A number of small community radio stations can be found in small villages or disadvantaged areas outside big cities where several mainstream local radio stations also operate (ORTT Database, 2008). Surprisingly, more small community stations have been launched in the eastern part of the country, where people are struggling with economic and social problems, than in the western, so-called 'rich' part of Hungary (Gosztonyi, 2007).

Each period is characterised by particular features, but to understand the quick growth of religious community radio stations this article mainly focuses on the changes around 2010. Although the Church has a smaller place in the everyday life of most of the Hungarians compared with Polish people, FideszHungarian Civic Alliance (former Alliance of Young Democrats) and Christian Democratic People's Party (KDNP) in coalition won two supermajorities in the National Assembly (both in 2010 and 2014 elections) and have a majority in Parliament. This explains well the growing number of licences won by religious broadcasters. This article examines Act CLXXXV of 2010 on media services and mass media (Parliament of the Republic of Hungary, 2010), as this regulation changed every single aspect of the life of community radios, and contains-unlike the previous regulation-an unconventional vision of community media. In Hungary, community radio was legitimised and functioning from 1996. By the end of 2010 there were 68 small community radio stations across the country, none of which was a religious radio station. Since the beginning of 2011, the new law has made it much more difficult for them to operate, and the number of community radios fell to 44 . On the other hand, this created the chance to establish religious community broadcasters. Many people claim that there is a danger that the real principles of the community radio will be lost in Hungary, and as data shows the present practice might easily lead to the disappearance of genuine community radio activity in Hungary and business and religion oriented community radio will flourish. ${ }^{17}$

\subsection{A New Approach to Community Media in Hungary}

After the general elections in the spring of 2010, life in Hungary changed in a number of ways. Legislation and enactment accelerated ${ }^{18}$ and non-governmental voices had limited influence during these processes. A new era began for community broadcasting in Hungary as the 2010 law CLXXXV relating to Media Services and Mass Media was passed on 22 December and came into force on 1 January 2011 (Brouillette \& van Beek, 2012). On the one hand, the sector was satisfied with the fact that the community media service as such was codified, on the other hand the Hungarian Federation of Free Radios realized that the definition was formulated inappropriately in the regulations. Paragraph 66

17 To give a brief summary of the 20 years of community broadcasting in Hungary seems impossible taking into account the length of this article, but there are several publications for those who are interested (Brouillette \& van Beek 2012, Gosztonyi, 2009, Velics, 2012a, 2012b.).

18150 new or amended acts came out during the first year. 
of Chapter IV in the new media law gives a brief overview of the community media service category and some criteria, but it lacks several important elements, which are distinctive characteristic features of community radio activity, and as a new element it named the religious communities as target audience:

\section{Act CLXXXV of 2010 on Media Services and Mass \\ Media (Parliament of the Republic of Hungary, 2010) \\ Chapter IV, Article 66.}

Community Media Service Provision

(1) Linear community media services are intended to serve or satisfy the special needs for information of and to provide access to cultural programmes for a) certain social, national, or ethnic minority, cultural or religious communities or groups, or b) residents of a given settlement, region or coverage area, or

c) in the majority of their transmission time programmes aimed at achieving the objectives of public service media service provision set in Article 83.

The new law does not contain the previous 'small community radio' category ${ }^{19}$. Furthermore, this new regulation includes almost impossible requirements for the volunteer-based radio stations: regular coverage of the news of a given social or local community, providing cultural programmes, at least four-hour long programme every day, $66 \%$ of public service content, $50 \%$ of the music played must be Hungarian, etc. Stations still have the possibility of broadcasting six minutes of advertisements in a one programme hour. (Act CLXXXV of 2010 . $\S 66$. and $\S 36$ (1)) This new regulation also provided profitable advantages for local and regional broadcasters: a possibility to apply for registration as a linear community broadcaster with access to financial resources previously only intended for the community stations, as well as exemption from the broadcasting licence fee. The community media sector was aware of the hidden governmental intentions such as drawing a new media landscape and minimalizing the risk of critical-alternative voices; it was clear as a potential consequence from the very beginning. At the same time the sector was a bit short-sighted and focused only on the already coexistent players, but was totally unaware of the other risk, that a large number of new organizations would show interest in community media, and the new players, e.g. church radios, would step on the stage unexpectedly.

Apart from the difficulties, which came from the regulators, most community radio stations were and still are suffering from financial difficulties. Since the global financial crisis began, the Hungarian economy

${ }^{19}$ Licence is valid until expiry date, renewal is possible only under the new conditions. has become more vulnerable, the support coming from local business or from the local government has started to dwindle. The resources, which used to be available for non-profit organizations both on local and national levels, are diminishing. By mid 2011 some of the notfor-profit organizations, such as tele-cottages and owners of the community radio stations had run out of financial resources. However, the main changes went through by licensing.

\subsection{Regulatory Angle in Hungary}

During the first working period (01.01.2011-20.10.2011) of the newly established National Media and Infocommunications Authority ${ }^{20}$ there were 109 applicants for 35 community licences, and only a few winners. According to the database of the Hungarian Media Council (HMC Database, 2012a, 2012b) the following new stations got permits for broadcasting as community broadcasters:

\section{Local and regional level ${ }^{21}$ : 19 community radio li- cence (12 went to church radio) \\ 5 stations of Lánchíd Rádió (close to governing party) \\ 7 stations of Mária Rádió (catholic mission) \\ 2 stations of Katolikus Rádió (catholic) \\ 3 stations of Európa Rádió (reformed) \\ 1 station of Sárrét FM \\ 1 station of Friends-Lan, private company \\ Small community category: 8 new stations \\ 3 applications from private companies \\ 3 applications from individuals \\ 2 applications from local cultural associations.}

By the end of December 2011 the majority of those stations, which had received a new linear community

\footnotetext{
20 The National Media and Infocommunications Authority participates in the implementation of the Government's policyas defined by law -in the areas of frequency management and communications. The Authority comprises the following entities with independent powers: President of the National Media and Infocommunications Authority, the Media Council of the National Media and Infocommunications Authority and the Office of the National Media and Infocommunications Authority. The Authority reports to Parliament on its activities on an annual basis. In relation to the communications sector, the Authority is responsible for ensuring the smooth and effective functioning and development of the communications market, for safeguarding the interests of the users and of those pursuing communications activities, for fostering the development and maintenance of fair and efficient competition within the electronic communications sector, and for the supervision of legal compliance of the conduct of organizations and persons pursuing communications activities. (Act CLXXXV of $2010 \S$ 109-110.)

${ }^{21}$ For comparison the two "old" community radios in this category: Tilos Rádió and Civil Rádió have had good international reputation as free radios for 20 years.
} 
media service provider status were professional, local, regional commercial-style or religious radio stations. They paid employees and editors and operated without volunteers or a genuine community of radio listeners. On the local and regional level 19 new permits were mostly given to those who had strong links to the church or the governing party.

The situation was similar at the beginning of 2012, when the database of the Hungarian Media Authority included only 44 small community radio stations, new ones and remaining old ones together-in the face of the previous number (68) the loss was big (HMC Database, 2012a). Furthermore, a new phenomenon is prevailing nowadays. Those companies and organizations, who want to build a media-empire, establish one or two companies using them to apply for a licence in different sites, and after gaining the licence they easily get more sites and frequencies for expanding the coverage area. They can then broadcast mainly the same content on different sites. Act CLXXXV of 2010. §71 (1) refers to the maximum number of licences as follows:

Those authorised to provide analogue linear radio media services based on a public contract or broadcasting agreement shall have the right to simultaneously provide

a) maximum one national analogue linear radio media service,

b) maximum two regional and four local analogue linear radio media services, or

c) maximum twelve local analogue linear radio media services.

This means cheaper operations (only a small number of staff on each site, apart from the central staff), larger coverage area (all over the country) and more potential audience, which makes them preferable for the advertisers, etc. However, while it seems a good business model, in the meantime the main feature of community radio has been lost. Volunteer based operation is questionable, access is limited; plurality of opinions and attitudes is disappearing.

According to the database of the Hungarian Media Council saved on 17. October 2014, there are 20 broadcasters on regional level: 15 community and 5 commercial (See Table 1. Colours were used to highlight the dominance of different churches).

Among regional community broadcasters there are still two internationally well-known community radio stations: Tilos Radio and Civil Radio. They have the licences but there is a risk of losing them, as the authority tries to find weak points in their renewal applications. Tilos and Civil have been operating for more than 20 years with a common feature: using only one frequency on one coverage area: Budapest. Among the newcomers, the big winners are church radio stations and Lánchíd Rádió, whose ownership is said to be re- lated to Infocenter Ltd., the right-wing owner of the sole commercial radio station that can be heard throughout the country: Class FM (Nagy, 2012, p. 5). Lánchíd Rádió uses 9 frequencies covering mainly the western part of the country. The Catholic Church established two organizations to apply for licences. The Hungarian Catholic Church Ltd. has won 2 licences and uses 13 frequencies all over the country, while the Hungarian Catholic Church Foundation also has 2 licences and uses 4 frequencies in the north-eastern part of the country. The Reformed Church, using two applicant organizations, has received 2 licences and uses 3 frequencies, also in the north-eastern part of the country. Mária Rádió uses 12 frequencies, covering the middle and the western part of the country. All other 5 community broadcasters on the regional level still have a set of basic features: one owner, one radio, one licence, one frequency, one location.

27 broadcasters still have the licence of a small community radio, working on a strictly limited coverage area of one geographical location, basically it means only $1 \mathrm{~km}$ stereo broadcast and $2 \mathrm{~km}$ mono broadcast with a very limited transmitter capacity. The loss of "old" community radios is huge in this category. Community radios, which operated for many years in villages or small towns or at universities, were closed down. This category is not so interesting for church radios because of the limited criteria of operating, the exception is the Evangelistic Church, whose first ever radio station-Credo Radio-operates on the technical basis of a former university radio in Szombathely (See Table 2).

On the local level there are 103 broadcasters (30 community and 73 commercial). Gaining a licence for local broadcasting means a wider coverage area for church radio stations. Using both opportunities (regional broadcasting and local broadcasting) means optimized operation that enables the building up of a media empire of the Church that can be heard throughout the country. Mária Rádió has 8 licences, the Catholic Church has 7 licences, the Reformed Church has 4 licences, Lánchíd Rádió has 2 licences and works on 5 locations, different business owners have 8 licences, and Radio Monoster, a Slovenian non-profit radio, has 1 licence and uses 2 frequencies due to the geographical need next to the Slovenian border. In comparison to the increasing number of church radio stations licensed since 2011, only a small number of non-church operations have been granted licences (See Table 3).

Today, Church radio stations not only cover the main cities of Hungary, but offer a wide choice of different religious stations in some sites. E.g. for the inhabitants of Szombathely with 80.000 residents, a county town next to the Austrian border, a Catholic radio station and an Evangelistic radio station can be heard, alongside two commercial channels, while the 
only small community radio of the University of WestHungary Berzsenyi Rádió had to stop operations because of unfavourable changes of the media regulations. The radio studio is now used by the Evangelistic radio station. It is worth noting that the latest statistics show that $52 \%$ of people are Roman Catholics; while only $2.7 \%$ are of the Evangelical faith in this region. (KSH, 2011).

Table 1. Linear community media service providers on regional level.

Linear community media service providers on regional level

\begin{tabular}{|c|c|c|c|}
\hline $\begin{array}{l}\text { Name of the media } \\
\text { service provider }\end{array}$ & $\begin{array}{l}\text { Name of the } \\
\text { radio }\end{array}$ & Site and frequency & Claim started $\mathrm{y} / \mathrm{m} / \mathrm{d}$ \\
\hline $\begin{array}{l}\text { Müsor-Hang Zrt. } \\
\text { Tilos Kulturális } \\
\text { Alapítvány }\end{array}$ & $\begin{array}{l}\text { Gazdasági Rádió } \\
\text { Tilos Rádió }\end{array}$ & $\begin{array}{l}\text { Budapest 105,9 MHz } \\
\text { Budapest 90,3 MHz }\end{array}$ & $\begin{array}{l}2002.11 .05 \\
2002.11 .06 .22\end{array}$ \\
\hline FM4 Rádió Kft. & Mária Rádió & $\begin{array}{l}\text { Budapest 94,2 MHz + Komárom 88,3 } \\
\text { MHz + Vác 94,1 MHz + Gyál 98,9 MHz + } \\
\text { Monor 106,3 MHz + Pécel 91,7 MHz + } \\
\text { Dömös 104,9 MHz + Komló 91,4 MHz + } \\
\text { Piliscsaba 104,2 MHz + Esztergom 97,4 } \\
\text { MHz + Dabas 97,5 MHz + Zalaegerszeg } \\
\text { Tarr company network }\end{array}$ & 2002.11.06. \\
\hline $\begin{array}{l}\text { Aeriel Rádió } \\
\text { Műsorszóró Kft. }\end{array}$ & Klasszik Rádió & Budapest 92,1 MHz & 2002.11 .09 \\
\hline Rádió Q Kft. & Rádió Q & Budapest 99,5 MHz & 2006.10 .27 \\
\hline Lánchíd Rádió Kft. & Lánchíd Rádió & $\begin{array}{l}\text { Budapest 100,3 MHz + Székesfehérvár } \\
\text { 106,6 MHz + Balatonfüred 96, } 2 \mathrm{MHz}+ \\
\text { Zalaegerszeg 88,3 MHz + Keszthely 93,4 } \\
\text { MHz + Dunaújváros 99,1 MHz + Győr } \\
88,1 \mathrm{MHz}+\text { Tatabánya 107,0 MHz + } \\
\text { Szombathely 97,1 MHz }\end{array}$ & 2006.10 .28 \\
\hline $\begin{array}{l}\text { Európa Rádió } \\
\text { Nonprofit Kft. }\end{array}$ & $\begin{array}{l}\text { Európa Rádió } \\
100,5\end{array}$ & Nyíregyháza 100,5 MHz & 2008.03.29. \\
\hline $\begin{array}{l}\text { Magyar Katolikus Rádió } \\
\text { Zrt. } \\
\text { Magyar Katolikus Rádió } \\
\text { Zrt. }\end{array}$ & $\begin{array}{l}\text { Magyar Katolikus } \\
\text { Rádió 107,4 MHz } \\
\text { Magyar Katolikus } \\
\text { Rádió }\end{array}$ & $\begin{array}{l}\text { Szombathely 107,4 MHz + Zalaegerszeg } \\
\text { 92,9 MHz } \\
\text { Székesfehérvár 96,1 MHz + Budapest } \\
\text { 102,1 MHz + Esztergom 92,5 MHz + Vác } \\
\text { 97,9 MHz + Veszprém 94,6 MHz + Mór } \\
89,0 \mathrm{MHZ}+\text { Sárbogárd 96,6 MHz + } \\
\text { Tapolca 101,8 MHz + Kiskőrős 91,7 MHz } \\
\text { + Kalocsa 94,5 MHz + Dunaföldvár 104,1 } \\
\text { MHZ }\end{array}$ & $\begin{array}{l}2011.03 .26 . \\
2011.04 .20\end{array}$ \\
\hline Inforádió Kft. & Inforádió & Budapest $88,1 \mathrm{MHz}$ & 2012.09.01. \\
\hline $\begin{array}{l}\text { Magyar Katolikus Rádió } \\
\text { Alapítvány }\end{array}$ & $\begin{array}{l}\text { Szent István Rádió } \\
91,8\end{array}$ & Eger 91,8 MHz + Gyöngyös 102,2 MHz & 2012.12.20. \\
\hline $\begin{array}{l}\text { Magyar Katolikus Rádió } \\
\text { Alapítvány }\end{array}$ & $\begin{array}{l}\text { Szent István Rádió } \\
95,1\end{array}$ & Miskolc 95,1 MHz + Encs 95,4 MHz & 2012.12.20. \\
\hline $\begin{array}{l}\text { Civil Rádiózásért } \\
\text { Alapítvány }\end{array}$ & Civil Rádió & Budapest 98,0 MHz & $2012.12 .21 . .^{23}$ \\
\hline $\begin{array}{l}\text { Európa Rádió } \\
\text { Nonprofit Kft. }\end{array}$ & Európa Rádió & $\begin{array}{l}\text { Miskolc 90,4 MHz + Mezőkövesd 102,1 } \\
\text { MHz }\end{array}$ & 2013.04.06. \\
\hline Klubrádió Zrt. & Klubrádió & Budapest 92,9 MHz & 2014.02.14. \\
\hline
\end{tabular}

Notes: Origin of data: Database of Hungarian Media Council-17. 10. 2014. Colours: Mária Rádió-grey, Catholic Church-yellow, Reformed Church-blue.

22 Tilos Rádió started broadcasting on 1991.08.21., their licence was renewed several times by the authority.

${ }^{23}$ Civil Rádió got licence first on 1995.09.01., their licence was renewed several times by authority. 
Table 2. Ownership of small community radio stations.

Ownership of small community radio stations

\begin{tabular}{ll}
\hline NGO: foundation, association & 11 \\
School, university & 2 \\
company and business & 9 \\
individual person & 4 \\
Church & 1 \\
\hline
\end{tabular}

Notes: Origin of data: Database of Hungarian Media Council-17. 10. 2014. Colour: Evangelistic Church-green.

Table 3. Linear community media service providers on the local level.

\begin{tabular}{|c|c|c|c|}
\hline \multicolumn{4}{|c|}{ Linear community media service providers on the local level } \\
\hline $\begin{array}{l}\text { Name of the media service } \\
\text { provider }\end{array}$ & Name of the radio & Site and frequency & $\begin{array}{l}\text { Claim started } \\
\mathrm{y} / \mathrm{m} / \mathrm{d}\end{array}$ \\
\hline Fekete Júlia (individual) & VÁR FM Rádió Kisvárda & Kisvárda 93,4 MHz & 2004.12.03. \\
\hline Médiahíd Kft. & Híd Rádió & Telkibánya 100,6 MHz & 2006.03 .15 \\
\hline Hegyalja Média Kft. & Szent István Rádió -Tokaj & Tokaj 101,8 MHz & 2006.03 .17 \\
\hline Magyar Jazz Rádió Kft. & Jazzy Rádió & Dél-Budapest 90,9 MHz & 2006.10.27. \\
\hline Európa Rádió Nonprofit Kft. & Európa Rádió 90,4 & Kisújszállás 103,2 MHz & 2007.05 .08 \\
\hline $\begin{array}{l}\text { Magyarországi Mária Rádió } \\
\text { Közhasznú Alapítvány }\end{array}$ & Mária Rádió Bakony & Ajka 93,2 MHz & 2010.11.24. \\
\hline Európa Rádió Nonprofit Kft. & Európa Rádió 94,4 & Debrecen 94,4 MHz & 2011.03.20. \\
\hline Európa Rádió Nonprofit Kft. & Európa Rádió 87,9 & Szeged 87,9 MHz & 2011.03.20. \\
\hline FM4 Rádió Kft. & Mária Rádió Völgyhíd & Veszprém 95,1 MHz & 2011.03.26. \\
\hline $\begin{array}{l}\text { Magyarországi Mária Rádió } \\
\text { Közhasznú Alapítvány }\end{array}$ & Mária Rádió Palota & Várpalota 90,0 MHz & 2011.04.05. \\
\hline Plusz Rádió Kft. & Győr Plusz Rádió & Győr $100.1 \mathrm{MHz}$ & 2011.04.20. \\
\hline Sárrét Média Bt. & Sárrét FM & Püspökladány 91,8 MHz & 2011.06.28. \\
\hline Mária Rádió Frekvencia Kft. & Mária Rádió Celldömölk & Celldömölk 92,5 MHz & 2011.07.12. \\
\hline Mária Rádió Frekvencia Kft. & Mária Rádió Mór & Mór 92,9 MHz & 2011.07.12. \\
\hline Mária Rádió Frekvencia Kft. & Mária Rádió Pápa & Pápa 90,8 MHz & 2011.07.12. \\
\hline Mária Rádió Frekvencia Kft. & Mária Rádió Sárvár & Sárvár 95,2 MHz & 2011.07.12. \\
\hline $\begin{array}{l}\text { Magyar Katolikus Rádió } \\
\text { Alapítvány }\end{array}$ & Szent István Rádió 94,0 & Hatvan $94,0 \mathrm{MHz}$ & 2012.12.20. \\
\hline $\begin{array}{l}\text { Magyar Katolikus Rádió } \\
\text { Alapítvány }\end{array}$ & Szent István Rádió 90,6 & Sátoraljaújhely 90,6 MHz & 2012.12.20 \\
\hline $\begin{array}{l}\text { Szlovén Rádió Közhasznú } \\
\text { Nonprofit Kft. }\end{array}$ & Radio Monoster & $\begin{array}{l}\text { Szentgotthárd 100,6 MHz + } \\
\text { Felsőszölnök 97,7 MHz }\end{array}$ & 2013.01.01. \\
\hline Fehérvár Médiacentrum Kft. & Vörösmarty Rádió & Székesfehérvár 99,2 MHz & 2013.01.30. \\
\hline Lánchíd Rádió Kft. & Lánchíd Rádió Pécs & $\begin{array}{l}\text { Pécs } 94,6 \mathrm{MHz}+\text { Kaposvár } \\
97,5 \mathrm{MHz}+\text { Szigetvár } 98,9 \\
\text { MHz + Siklós } 88,6 \mathrm{MHz}\end{array}$ & 2013.03.20. \\
\hline Friss Rádió Kft. & FM90 Campus Rádió & Debrecen 90,0 MHz & 2013.04.05. \\
\hline Magyar Katolikus Rádió Zrt. & Magyar Katolikus Rádió 92,3 & Debrecen 92,3 MHz & 2013.04.19. \\
\hline $\begin{array}{l}\text { Magyar Katolikus Rádió } \\
\text { Alapítvány }\end{array}$ & Szent István Rádió 96,4 & Törökszentmiklós 96,4 MHz & 2013.04.19. \\
\hline Magyar Katolikus Rádió Zrt. & Magyar Katolikus Rádió 102,6 & Kaposvár 102,6 MHz & 2013.08.08. \\
\hline Halas Rádió Nonprofit Kft. & Halas Rádió & Kiskunhalas 92,9 MHz & 2013.09.05. \\
\hline Európa Rádió Nonprofit Kft. & Európa Rádió FM 100,0 & Sátoraljaújhely $100,0 \mathrm{MHz}$ & 2013.10.09. \\
\hline Mária Rádió Frekvencia Kft. & Mária Rádió Cegléd & Cegléd 88,3 MHz & 2013.11.08. \\
\hline Magyar Katolikus Rádió Zrt. & Magyar Katolikus Rádió 101,2 & Pécs $101,2 \mathrm{MHz}$ & 2013.11.14. \\
\hline Lánchíd Rádió Kft. & Lánchíd Rádió 100,2 & Szeged $100,2 \mathrm{MHz}$ & 2014.02 .06 \\
\hline
\end{tabular}




\section{Poland}

\subsection{The History of Community Broadcasting}

Polish independent media has a long and interesting history. In Poland, samizdat publications started in 1976 and gradually undermined the official information system (Dobek-Ostrowska, 2013). Pluralistic media were considered as one of the founding elements of a "self-managed republic" claimed by the trade union Solidarność, the first independent trade union of the People's Republic of Poland (Brodzki \& Surdykowski, 1981). Before 1989 there were plenty of illegal, independent press titles. What is more, in 1982 a pirate radio station "Radio Solidarity" started broadcasting (Majchrzak, 2010).

However, in the first Broadcasting Act in Poland which was passed in 1992, there was no recognition of the third tier of broadcasting. Only public and commercial broadcasters got a chance to apply for licences. In practice, some not fully commercially oriented entities, such as universities and churches, also applied for commercial licences. The situation changed in 2001, when a new category in the media law- "social broadcaster" (nadawca społeczny)-was introduced. This category was thought similar to some extent to what is called "community broadcaster" in some other countries.

\section{Law on Radio and Television Broadcasting 1992}

(Parliament of the Republic of Poland, 1992)

"Social broadcaster" shall mean a broadcaster who:

1) propagates learning and educational activities, promotes charitable deeds, respects the Christian system of values, being guided by the universal principles of ethics, and strives to preserve national identity in the programme service,

2) does not transmit programmes or other broadcasts referred to in Article 18 paragraph 5 within the programme service,

3) does not transmit commercial communications, 4) does not charge any fees for transmission, retransmission or reception of the programme service.

The following entities may apply to the National Broadcasting Council to be granted the status of a "social broadcaster":

1) an association, within the framework of implementing its statutory objectives,

2) a foundation, within the framework of implementing its statutory objectives,

3) a church or a religious legal person of a given church, or a religious organisation whose status is regulated by an Act of Parliament.

It was also specified that social broadcasters are exempt from a licence fee. In comparison to community media definitions there was a strong emphasis on the fact that religious institutions and a Christian system of values are very welcome within this legal framework. The person who was actively involved in lobbying for this regulation was Tadeusz Rydzyk, the director of the nationwide Catholic radio station Radio Maryja, which became the biggest beneficiary of this media regulation. The licence fee-not very high in the case of small local stations-becomes a big sum when talking about a nationwide station (Sygut, 2005).

The legally recognised third tier of broadcasting in Poland was for many years actively and exclusively used by religious radios. The exclusion of 'social broadcasters' from the advertising market, combined with no other governmental support for such entities, resulted in a lack of interest in applying for such a status among, for example, NGOs. They were not formally excluded but in practice only religious broadcasters were able to collect money for broadcasting without available advertising revenues. In 2013 there were only eight radio 'social broadcasters'. All of them were connected to the Church-seven broadcast locally and one was a powerful nationwide radio station Radio Maryja. Additionally, in 2014 there were 2 special cable TV licences given to a housing estate TV Sadyba and Catholic TV Serbinów (See Table 4.). Apart from Radio Maryja, the operating 'social broadcasters' are small and locally oriented. One of them-Radio Orthodoxia broadcasts from Białystok, not for Catholics but for Orthodox Christians and is part of the Białystok-Gdańsk Orthodox Diocese.

The fact that for years social broadcasting was limited to religious broadcasting very badly influenced the understanding of the idea of the community tier of broadcasting in Poland. As research showed, not only the Polish society but also representatives of local broadcasters and those run by NGOs often equate the third sector of broadcasting or community broadcasting with religious broadcasting, and are not aware of the role and principles of community media operation in Europe. This is one of the reasons why community media development in directions other than religious is so complicated in Poland (Doliwa, 2013; Jędrzejewski \& Doliwa, 2013).

The problem of overrepresentation of religious broadcasters among 'social broadcasters' was noticed by the National Broadcasting Council, which in 2012 announced public consultations on broadcasting related issues, including a 'social broadcaster' status (Jędrzejewski \& Doliwa, 2013). However, the regulator does not have a legislative initiative and up to now there is little political will to change the existing system. Yet the fact that the Ministry of Culture and National Heritage prepared a project of amendments in the Broadcasting Act with some expected changes in the model of the third sector of broadcasting is what currently gives some hope for changes in the situation of the third sector in Poland (Polish Ministry of Culture and National Heritage, 2015). The project 
Table 4. Social broadcasters in Poland 2014.

\begin{tabular}{|c|c|c|c|}
\hline & Number of licence & Name of the media service provider & Name of the station \\
\hline 1 & $003 / K / 2008-R$ & $\begin{array}{l}\text { Prowincja Warszawska Zgromadzenia Najświętszego } \\
\text { Odkupiciela (Redemptoryści) }\end{array}$ & Radio Maryja \\
\hline 2 & 015/K/2008-R & Klasztor OO. Paulinów Jasna Góra-Częstochowa & Radio Jasna Góra \\
\hline 3 & 068/K/2011-R & Prawosławna Diecezja Białostocko-Gdańska & Radio Orthodoxia \\
\hline 4 & 075/K/2011-R & Archidiecezja Przemyska Obrządku Łacińskiego & $\begin{array}{l}\text { Radio Fara-Rozgłośnia } \\
\text { Archidiecezji Przemyskiej }\end{array}$ \\
\hline 5 & 077/K/2011-R & Archidiecezja Wrocławska & Katolickie Radio Rodzina \\
\hline 6 & 078/K/2011-R & Diecezja Kaliska & $\begin{array}{l}\text { Radio Rodzina Diecezji } \\
\text { Kaliskiej }\end{array}$ \\
\hline 7 & $104 / K / 2011-R$ & $\begin{array}{l}\text { Parafia Rzymsko-Katolicka p.w. Św. Jana Chrzciciela w } \\
\text { Zbroszy Dużej }\end{array}$ & Radio Katolickie Zbrosza Duża \\
\hline 8 & $199 / K / 2013-R$ & Rzymsko-Katolicka Parafia p.w. Nawiedzenia NMP & $\begin{array}{l}\text { AIN KARIM Radio Skomielna } \\
\text { Czarna }\end{array}$ \\
\hline 9 & TK-0028/05 & Stowarzyszenie Sadyba z siedzibą w Warszawie & Telewizja Sadyba \\
\hline 10 & 543/2013-TK & $\begin{array}{l}\text { Parafia Rzymsko-Katolicka p.w. Matki Bożej } \\
\text { Nieustającej Pomocy w Tarnobrzegu }\end{array}$ & Katolicka Telewizja Serbinów \\
\hline
\end{tabular}

Source: National Broadcasting Council.

was undergoing public consultation until the $4^{\text {th }}$ March 2015. However, the past few years have seen several attempts to amend the Broadcasting Act in the field of the system of financing of public media in Poland, as well as in the third sector broadcasting model, none of which was successful.

\subsection{A Special Position of the Religious Broadcasting in Poland}

The special role of the Catholic Church in Polish society has its roots in the history of Poland. The bond between Church and society appears to have strengthened in difficult moments of Polish history, like the 3 partitions of the country in 1772, 1793, and 1795 when the Church was a depositary of the national culture and tradition. It was again apparent after the Second World War when Poland became a part of the Soviet bloc and the Church supported Polish society in its striving for independence (Stetkiewicz, 2013). It is noteworthy that after the Nazi extermination of Polish Jews, post-war changes of the national borders and relocation of certain ethnic minorities (both into and out of Poland), the Polish population became 96.6\% Roman Catholic (Casanova, 2005, p. 164). After 1989 the new government-taking into account the special role of the Polish Church in the communist period and wanting to compensate for the Catholic Church persecutions before 1989-was willing to make large concessions in relation to the Roman Catholic Church in Poland. The expression of this special attitude was the Act of the 17th of May 1989 about the state attitude towards the Roman Catholic Church in PRL (Parliament of the Peoples Republic of Poland, 1989). By virtue of this law, the Church, before any other entity, secured the right to broadcast. In 1991 the Ministry of Communications gave the Church the first round of fre- quencies (KRRiT, 1998, p. 130). The special role of the Church in the broadcasting system was then confirmed in the Broadcasting Act (Parliament of the Republic of Poland, 1992). To date there exists a controversial paragraph in this document, stating that programmes or other broadcasts shall respect the religious beliefs of the public and especially the Christian system of values.

The current situation of religious broadcasting in Poland appears thus - the majority of stations joined a network called PLUS organised by a big commercial media group TIME (20 stations); Radio Vox-also connected with the group TIME broadcasts as crossregional station; 17 broadcasting entities remain independent; an additional 9 have a "social broadcasting status" (including one powerful nationwide radio station, Radio Maryja). There is also a terrestrial digital nationwide television Trwam. All in all, parishes, convents and dioceses have about 50 licences, which makes up almost a quarter of the total number of broadcasting stations in Poland (KRRiT, 2014). Most of the religious stations are financed from the advertising revenue (apart from social broadcasters) supplemented by donations (KRRiT, 2014).

The most influential station is the nationwide Radio Maryja, which was founded in Torun in 1991 by Tadeusz Rydzyk. As shown in Figure 1, this station also has the biggest budget at its disposal. The station is financed by its loyal listeners who also form a religious movement The Radio Maryja Family, whose members are especially elderly, poorer people. Despite a community based financial model, the station is definitely not community governed-the director of the station has always had a decisive voice and the station is usually closed to people who represent a point of view significantly different than that of the director. There have also been some examples of hate speech recorded in the programmes 
of Radio Maryja (Maszkowski, 2011). These points make this station, despite having a special licence for 'social broadcasting', significantly different to the community media in other European countries. Independent religious broadcasters not connected to a commercial network, and local 'social broadcasters' seem to be most similar to the community model. According to the data collected during interviews with representatives of these stations, in their own opinion, these stations follow to a greater or lesser extent all the points of the definition of community media taken from the Declaration of the Committee of Ministers on the role of community media in promoting social cohesion and intercultural dialogue, apart from the independence from religious institutions (Doliwa, 2014).

\section{Conclusions}

The analyses of documents related to community broadcasting in the EU, discussion with media experts and the overview of the situation of religious broadcasting in different countries showed the complexity of the problem of affiliation of religious broadcasting to the community media sector. There seems to be a general consensus that religious broadcasts could and should be part of the local community broadcasting programmes but the practice of giving community licences to religious entities with religion-oriented pro- grammes is often difficult to accept for media experts and community media activists.

The main concern about religious broadcasting in the community media scheme is related to two elements: accessibility and community ownership, which are the core values for community media. Such stations are frequently not completely open to the full spectrum of voices present in the local community they serve, and they are very rarely community governed. The owner of the licence is very often not a community but a religious institution.

The practices around Europe concerning religious broadcasting in the community media context are so varied that it is very difficult to indicate the main trend. However, in the countries where the spectrum share is unbalanced and the religious sector is becoming the major beneficiary of some of the community broadcasting regulations (like in Poland and Hungary) there is a risk that this sector can monopolize the field, and cause limitations in the diversity of the programming. These countries might be the main beneficiaries of a common European regulation. The analysis of documents, discussion with media experts and the overview of the situation of religious broadcasting in different countries has shown how difficult it is to even imagine (and realise in the future) a common regulation on community media for the whole Europe.

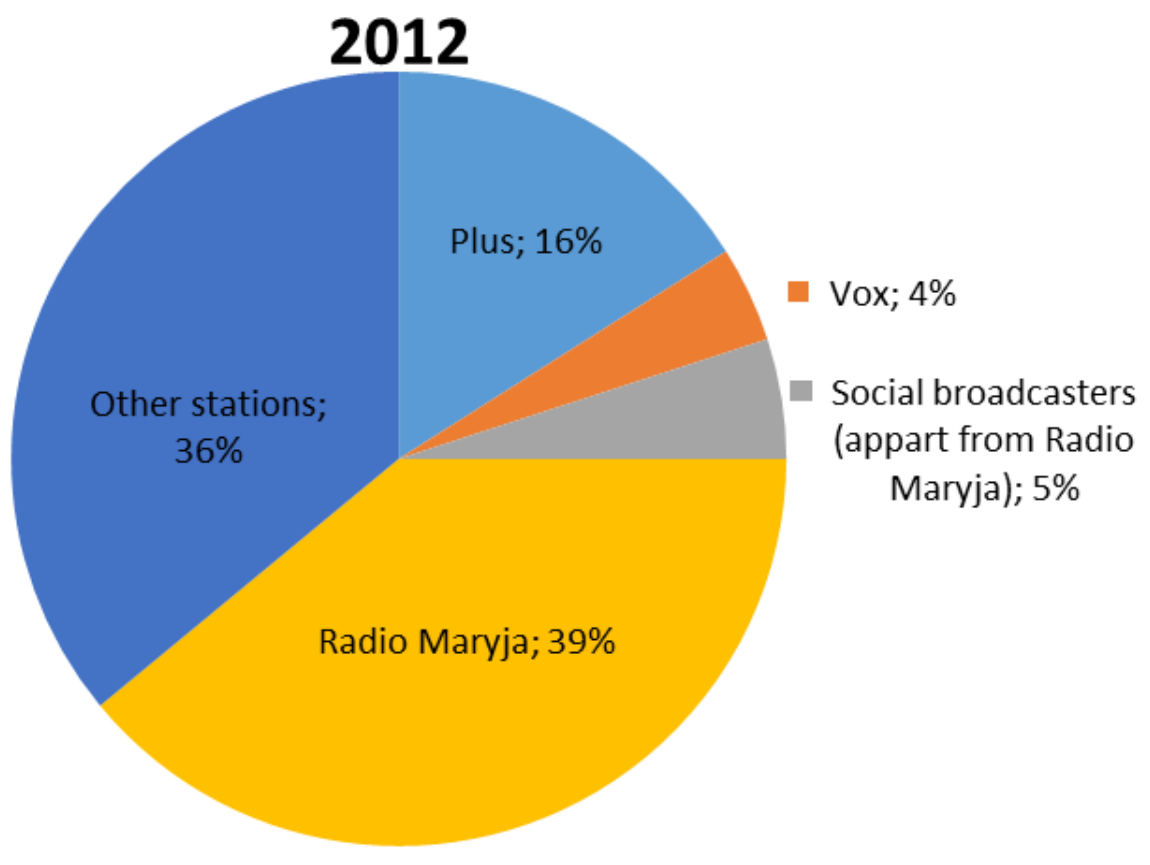

Figure 1. The incomes of religious broadcasters from the advertising market, subsidies and donations together in 2012. Source: National Broadcasting Council. 


\section{Acknowledgments}

The authors would like to thank the media experts and community media practitioners who shared their ideas and experiences about the discussed theme, which significantly contributed to the writing of this article.

\section{Conflict of Interests}

The authors declare no conflict of interests.

\section{References}

AMARC (1994). The community radio charter for Europe. Retrieved from http://www.amarc.org/index.php?p= Community_Radio_Charter_for_Europe

Belardi, N. (2014). An interview conducted by Urszula Doliwa and Gabriella Velics during the Bundesverband Freier Radios congress in Berlin/Potsdam Zukunftswerkstatt Community Media 2014, 8th November 2014.

Brodzki, S., \& Surdykowski J. (1981). Stan komunikacji społecznej u progu lat osiemdziesiątych. [The condition of social communication at the beginning of the eighties]. Retrieved from http://dlibra.karta.org.pl/ dlibra $/$ docmetadata id $=6430$

Brouillette, A., \& van Beek, J. (Eds.) (2012). Hungarian media laws in Europe. An assessment of consistency of Hungary's media laws with European practices and norms. Budapest: Center for Media and Communication Studies, Central European University.

Casanova, J. (2005). Public religions in the modern world. Kraków: Nomos.

CMFE. (2012). Community media mapping and rating project. Retrieved from https://docs.google.com/ spreadsheets/d/1hzhZ6Fs0qO1mOCPF5Ef5ftWkM9 zkW3ENvFV2sjdkZDw/pub?single=true\&gid=0\&outp ut=html

Committee of Ministers of the Council of Europe. (2009). Declaration of the Committee of Ministers on the role of community media in promoting social cohesion and intercultural dialogue. Retrieved from http://www.connexx-av.de/upload/m49a288b318ab 0_verweis1.pdf

Community Broadcasting Association of Australia, National Ethnic \& Multicultural Broadcasters' Council, Australian Indigenous Communications Association, RPH Australia, Australian Community Television Alliance, \& Christian Media Australia (2010). Voices and vision. Community broadcasting in Australia. Retrieved from http://www.cbaa.org.au/sites/default/ files/Voices\%20\%26\%20Vision\%20\%20All\%20About \%20Community\%20Broadcasting.pdf

Connolly-Ahern, C., Schejter, A., \& Obar, J. A. (2012). The poor man's lamb revisited? Assessing the state of LPFM at its 10th Anniversary. The Communication Review, 15(1), 21-44.
Cs. Kádár, P. (2004). Közösségi rádiózás [Community radio's broadcasting]. Budapest: MR.

Dobek-Ostrowska, B. (2013). Media landscapes in transition: Focus on Central and Eastern Europe. In MediaAcT. Final Research Report 2013 (pp. 36-37). Hamm: Griebsch \& Rochol Druck.

Doliwa U. (2013). Polish radio stations run by NGOsIdea, organization, programme. In G. Stachyra (Ed.), Radio a społeczeństwo (pp. 63-78). Lublin: Uniwersytet Marii Skłodowskiej-Curie.

Doliwa U. (2014). Religious radio stations in Poland: A community-oriented Catholic ghetto? A case study of Radio Niepokalanów. In M. Oliveira, G. Stachyra, \& G. Starkey (Eds.), Radio: The resilient medium (pp. 205217). Sunderland: Centre for Research in Media and Cultural Studies.

Doliwa U., \& Rankovic, L. (2014). Time for community media in Central and Eastern Europe. Central European Journal of Communication, 1(12), 18-33.

European Parliament. (2008). Resolution of 25 of September of 2008 of the European Parliament on Community Media in Europe (2008/2011(INI). Retrieved from http://www.europarl.europa.eu/sides/ getDoc.do?pubRef=-//EP//TEXT+TA+P6-TA-20080456+0+DOC+XML+V0//EN

Federal Communications Commission. (2014). Low power FM broadcast radio stations. Retrieved from http://www.fcc.gov/encyclopedia/low-power-fmbroadcast-radio-stations-Ipfm

Galiana, S. (2014). An interview made by Urszula Doliwa and Gabriella Velics during the Bundesverband Freier Radios congress in Berlin/Potsdam Zukunftswerkstatt Community Media 2014, 8th November 2014.

Gosztonyi, G. (Ed.) (2007). Kisközösségi rádiók Magyarországon [Community radios in Hungary-research report]. Budapest, Hungary: Civil Rádiózásért Alapítvány.

Gosztonyi, G. (2009). Past, present and future of the Hungarian community radio movement. In K. Howley (Ed.), Understanding community media (pp. 297 308). SAGE Publications.

HMC Database. (2012a). Database of small community radio broadcasters from the web-page of the Hungarian Media Council. Retrieved from http:// www.mediatanacs.hu/nyilvantartasok/1329206403_ kiskoz_mszolg_20120213.xls

HMC Database. (2012b). Database of local and regional radio broadcasters from the web-page of the Hungarian Media Council. Retrieved from http:// www.mediatanacs.hu/nyilvantartasok/1329206384_ helyi_korzeti_mszolg_20120213.xls

Jędrzejewski, S., \& Doliwa U. (2013). Local radio-An endangered species? The Polish case. Media Transformations, 10, 74-99.

KRRiT. (1998). Information about the main problems of radio and television in 1997. Retrieved from http:// www.krrit.gov.pl/Data/Files/_public/Portals/0/spraw 
ozdania/spr1998/inf1998.pdf

KRRiT. (2014). Information about the main problems of radio and television in 2013. Retrieved from http://www.krrit.gov.pl/Data/Files/_public/Portals/0 /sprawozdania/informacja.pdf

KSH. (2011). Hungarian Central Statistical Office, Database of latest census in 2011. Retrieved from http://www.ksh.hu/interaktiv/terkepek/mo/vallas.ht $\mathrm{ml}$

Lewis, P. (1984). Community radio: The Montreal conference and after. Media, Culture, and Society, 6, 137-150.

Lewis P. (2008). Promoting a social cohesion-The role of community media. Retrieved from www.amarc. org/conference_europe/document/Promoting_Socia I_Cohesion_The_Role_of_Communit_Media.pdf

Majchrzak, G. (2010). Niezależna działalność radiowa pod szyldem "Solidarność" 1980-1989 [Independent radio activity under the name "Solidarność" 19801989]. Nasz Dziennik, 200, 5.

Maszkowski R. (2011). Radio Maryja xenophobic incidents and hate speech. Retrieved from http:// www.radiomaryja.pl.eu.org/incidents.html

Nagy, K. (2012). A Médiatanács frekvencia pályáztatási gyakorlata 2010-2011 [The Media Council's tender procedures for broadcasting frequencies 2010-2011]. Retrieved from http://mertek.eu/sites/default/files/ reports/jelentes_palyaztatasi_gyakorlat.pdf

ORTT Database. (2008). National Radio and Television Commission, Register of small community radio broadcasters. Retrieved from http://www.ortt.hu/nyil vantartasok/1212656196kiskozossegi_20080604.xls

Parliament of the Republic of Hungary. (2010). Act CLXXXV of 2010 on media services and mass media. Retrieved from http://english.nmhh.hu/dokumen tum/164596/media_act_final_updated_140930.pdf

Parliament of the Republic of Hungary. (1996). Act I of
1996 on radio and television broadcasting. Retrieved from http://english.nmhh.hu/dokumentum/150103/ 1_1996_torv_media_en_lekt_20070514.pdf

Parliament of the Peoples Republic of Poland. (1989). Ustawa z 17 maja 1989 roku o stosunku państwa do Kościoła katolickiego w PRL, (Legal Act) Dz. Ust. 1989, poz. 154. Retrieved 14.09.2014 from: http:// mateusz.pl/dokumenty/ustawapk.htm

Parliament of the Republic of Poland. (1992). Law on radio and television broadcasting. Retrieved from http://www.krrit.gov.pl/en/for-broadcasters-andoperators/legal-regulations

Polish Ministry of Culture and National Heritage. (2015). The project of amendment in the Broadcasting Act from the $4^{\text {th }}$ February 2015. Retrieved from http://bip.mkidn.gov.pl/media/docs/konsultacje_pu b/2015/201502094_02_15_projekt_ustawy.pdf

Stetkiewicz, L. (2013). The role of the Catholic Church and polish religiosity. The Journal for the Sociological Integration of Religion and Society, 3(2), 1-17.

Sygut, T. (2005). Modlitwa na falach [A prayer on the waves]. Retrieved from http://www.przegladtygodnik.pl/pl/artykul/modlitwa-na-falach

Velics, G. (2012a). The changing situation of Hungarian community radio. In J. Gordon (Ed.), Community radio in the twenty-first century (pp. 265-281). Bern: Peter Lang.

Velics G. (2012b). Adaptation y supervivencia de las emisoras de radio comunitarias en Hungría [Adaption and survival of community radio stations in Hungary]. In M. Martínez Hermida, C. Mayugo i Mayó, \& Ana Tamarit Rodríguez (Eds.) (2012), Comunidad y Comunicación: prácticas comunicativas y medios comunitarios en Europa y América Latina [Community and communication: communicative practices and community media in Europe and Latin America] (pp. 97-114). Madrid: Editorial Fragua.

\section{About the Authors}

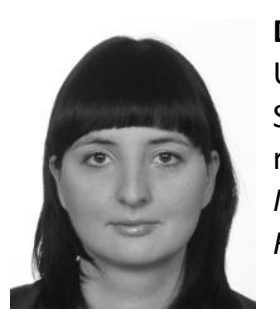

\section{Dr. Urszula Doliwa}

Urszula Doliwa is an Assistant Professor and former Vice Director of the Institute of Journalism and Social Communication at the University of Warmia and Mazury in Olsztyn, Poland. She is also the Secretary of the Community Media Forum Europe, member of the Editorial Board of the Polish journal Media-Culture-Social Communication, and the author of the book Radio studenckie w Polsce/Student Radio in Poland. Her research interests centre on community media.

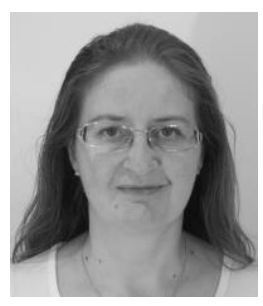

\section{Dr. Gabriella Velics}

Gabriella Velics is an Associate Professor and leader of the Department of Communication and Media at University of West-Hungary in Szombathely. She teaches sociology, PR and media relations and radio broadcasting. She is also the Vice-President of Community Media Forum Europe and member of the Advisory Board of the Montenegrin journal Media and Communication: International Scientific Journal of Media, Communication, Journalism and Public Relations. Her research focuses on the Hungarian community radio system and its function in social communication, journalism and media sociology. 